\title{
Descriptive Analysis of Patient Experience in Shanghai Primary and Tertiary Care Settings
}

\author{
Kyle Kai Ho Ng${ }^{1}$, Jonathan Gendron-Rossignol ${ }^{1}$, Chao Meng ${ }^{2}$, Yan Zhou², Peter Kuling ${ }^{1}$, Yuwei Wang ${ }^{1}$, \\ Dianne Delva ${ }^{1}$
}

${ }^{1}$ Faculty of Medicine, University of Ottawa

${ }^{2}$ Renji Hospital, Shanghai Jiao-Tong University School of Medicine (SJTUSM)

ABSTRACT

Context: China has recently undertaken a nationwide healthcare reform of primary care for its citizens. The new Ottawa-Shanghai Joint School of Medicine (OSJSM) entered this context of reform by developing family medicine training centres for its students. Objective: This study seeks to understand patients' demographic, perceptions of family medicine, and alignment of needs and values towards family medicine to inform the creation of these new centres.

Study Design: To this end, a culturally and linguistically appropriate patient experience survey was created and administered at two primary (CaoJiaDu and TangQiao Community Health Centers) and at a tertiary care centre (Renji Hospital). The survey consisted of questions on demographics, frequency of healthcare usage, satisfaction of care, barriers to access, prioritized values and perceptions of family medicine. It was administered to 400 patients conveniently sampled to have a balance of primary/tertiary settings.

Results: Despite common assumptions that Chinese patients may prefer specialist services, this study revealed a $68.3 \%$ preference for General Practitioners (GP) over Specialists. There was also overall agreement and preference for values of continuity, comprehensiveness, and coordination in healthcare.

Conclusion: These findings reveal that primary care is present in Shanghai and that the core values of family medicine are desired by a majority of respondents. Further analysis, qualitative corroboration and repeating the study in a wider population may be required for more generalizable conclusions, as this study in its current design was limited by convenience sampling.

RÉSUMÉ

Contexte: La Chine a récemment entrepris une réforme des soins de santé primaires à l'échelle nationale pour ses citoyens. La nouvelle École conjointe de médecine Ottawa-Shanghai (ÉCMOS) est entrée dans ce contexte de réforme en créant des centres de formation en médecine familiale pour ses étudiants.

Objectif: Cette étude vise à comprendre la démographie des patients, leurs perceptions de la médecine familiale et l'alignement de leurs besoins et de les valeurs vers la médecine familiale pour informer le développement de ces nouveaux centres.

Conception de l'étude: Dans ce but, un sondage culturellement et linguistiquement appropriée a été créée pour s'informer sur l'expérience des patients et a été administrée dans deux centres de santé primaires (CaoJiaDu et TangQiao) et dans un centre de soins tertiaires (Hôpital Renji). Le sondage comprenait des questions sur la démographie, la fréquence de l'utilisation des soins de santé, la satisfaction des soins, les obstacles à l'accès, les valeurs prioritaires et les perceptions de la médecine familiale. Ce sondage a été administrée à 400 patients commodément échantillonnés pour avoir une représentation équilibréé des centres de santé primaires et tertiaires.

Résultats: Malgré des hypothèses communes selon lesquelles les patients chinois pourraient préférer les soins spécialisés, cette étude a révélé une préférence de $68,3 \%$ pour les médecins généralistes plutôt que pour les spécialistes. II y avait aussi un accord global et une préférence pour les valeurs de continuité, d'intégralité et de coordination des soins de santé.

Conclusion: Ces résultats révèlent que les soins primaires sont présents à Shanghai et que les valeurs fondamentales de la médecine familiale sont souhaitées par une majorité de répondants. Une analyse plus approfondie, une corroboration qualitative et la répétition de l'étude dans une population plus large pourraient être nécessaires afin d'établir des conclusion plus généralisables, étant donné que cette étude, dans sa conception actuelle, était limitée par l'échantillonnage de commodité.

Keywords: Family Medicine; General Practice; Shanghai; China; Primary Care 
A mongst Chinese healthcare policy leaders, it is common consensus that the medical profession faces a crisis of patient-physician mistrust [1]. A recent World Bank report also highlights an impending healthcare driven fiscal crisis where "business as usual, without reform, would result in growth of total health expenditure from 5.6 percent of GDP in 2015 to 9.1 percent in 2035, an average increase of $8.4 \%$ per year in real terms" [2]. Both locally and internationally, it is recognized that challenges to the Chinese healthcare system will require a range of solutions that includes, but is not limited to, strengthening the primary healthcare system and raising the status of primary care workers [1,2]. Indeed, this concurs with primary care literature that provides consistent evidence that countries with a strong primary care system have better health outcomes delivered more equitably and at lower cost [3].

Since the Chinese Communist Revolution of 1949, healthcare in China has undergone multiple transformations. Most notably, reforms began with an equality-based, planned economy phase from 1949 to the 1980s, followed by a market oriented approached in the late 1980s [4]. Most recently in 2009, China launched a healthcare reform plan, with the development of a primary care system as one of its main goals [5]. However, almost eight years after the unveiling of this healthcare plan, China still suffers from "severe maldistribution of human resources and lack of primary care practitioners (PCPs), lack of a functional gate-keeping mechanism, the low educational attainment of PCPs, and the detrimental elements of health reforms" [6]. In practical terms, this has resulted in a tertiary care oriented system that focuses on revenue generation and allows patients a direct à-la-carte selection of specialist chosen from a menu of doctors located in hospital lobbies [4]. Adding to the confusion, different models of primary care, as well as different residency program reforms are amongst the continual changes being piloted at various municipal and provincial levels $[7,8]$. This has contributed to the continual stagnation of the ratio of medical doctors who choose to become General Practitioners (GP), which stands at a relatively low 5.3\% [9]. In comparison, over $51.7 \%$ of Canadian physicians are family doctors [10] despite the relatively comparable proportion of doctors to population in the two countries, with 1.9 and 2.1 physicians per thousand capita in China and Canada, respectively [11].

In October 2014, the University of Ottawa entered this fluid reform landscape by partnering with the Shanghai Jiao Tong
University School of Medicine (SJTUSM) to open the OttawaShanghai Joint School of Medicine (OSJSM) at the SJTUSM affiliated Renji Hospital in Shanghai [12]. In order to implement a North American undergraduate medical education program in China, the joint school requires adequate primary care exposure for its students to comply with standards of the Canadian Accreditation Committee for Canadian Medical Schools (CACMS) [13]. The OSJSM International Family Medicine Clinic was inaugurated in October 2015 with the long-term goal of providing Canadian-inspired family medicine training for students, residents and physicians and delivering primary care to patients speaking Mandarin Chinese or English. This initiative provided a unique opportunity to study the rapidly evolving Chinese primary care landscape in order to better understand the impact primary care may or may not have, and to inform the continued development of OSJSM Family Medicine training sites in Shanghai [14].

In this context of Sino-Canadian partnership and national healthcare reform in China, we chose to explore perceptions of family medicine among patients attending General Practice clinics and a tertiary hospital, to ultimately inform the development of the OSJSM Family Medicine training sites to meet the clinical and social realities of Shanghai. In particular, the study was developed around the following three objectives:

1. To describe the demographic characteristics of patients attending Shanghai tertiary hospitals and community health clinics;

2. Understand the satisfaction of patients attending tertiary healthcare clinics in comparison to General Practice;

3. Gather insight on the general knowledge, perceptions, needs and values of Shanghai patients with regards to family medicine.

Our hypothesis for this study was twofold. Firstly, we expected that the majority of patients would prefer receiving healthcare from specialized tertiary hospitals as compared to General Practice community clinics. This projection was based on reports that patients perceive GPs as less trustworthy and providing poorer quality of care [5]. Secondly, we hypothesized that patients may perceive the introduction of family medicine favourably as an alternative to the existing system, due to the continuity, comprehensiveness and coordination of care that family medicine can provide. This was based on accounts that the current General Practice system is faced with the "absence 
of primary care gatekeeping, weak coordinated care, and a lack of an effective referral system" [5].

\section{METHODS}

A culturally and linguistically appropriate survey was developed in English and then translated to Mandarin Chinese (Appendix 1\&2). This was adapted from various Health Quality Ontario surveys, modified to accommodate our particular objectives and revised for medical and cultural orientation [15]. The final survey consisted of 2 identity-verifying questions, 6 basic demographic questions, and a combination of yes/no questions, rank order questions, multiple choice questions, and five-point Likert scale questions (Strongly Agree, Somewhat Agree, Neutral, Somewhat Disagree, Strongly Disagree) (Appendix 1). One notable exception was the use of a four-point Likert scale question, with the removal of a neutral option, for the evaluation of General Practice Doctor preference instead of a Hospital Doctor. Consultation for linguistic and cultural translation was provided by the Office of Internationalization at University of Ottawa, and validated by physician partners at the SJTUSM. In particular, survey questions were reviewed to respect cultural customs (e.g. personal questions) and edited with commonly used vocabulary in Shanghai to ensure patient comprehension. Pilot surveys were then provided to physicians at various sites in Shanghai, which again prompted further revisions. The study was submitted for review and was approved by the Research Ethics Board of the Ottawa Health Sciences Network and the Ethics Committee of the Renji Hospital in Shanghai.

The final survey was distributed to a sample of 400 patients across six sites representing both primary care and tertiary care settings in Shanghai: 100 at CaoJiaDu Community-HealthCenter (CJD); 100 at TangQiao Community-Health-Center (TQ); and 200 at Renji Hospital tertiary care settings including Geriatrics-Outpatient, Emergency/General-Outpatient; VIP Inpatient/Outpatient and Emergency In-patient. The outpatient to inpatient ratio was 150 to 50 . The participant sample was established at these sites because of their affiliation to the Shanghai Jiao Tong University School of Medicine, the University of Ottawa's international partner, and the convenience of having partner physicians and trainees willing to support the study and help collect data.

The sampling model was chosen to identify perceptions and characteristics of the patient groups that receive care at primary and tertiary care settings. Participants were 18 years of age or older and provided consent to complete the survey. Surveys were distributed and collected with the aid of volunteer medical residents-in-training and nurses from the CJD and TQ community health centers, the department of geriatrics and the emergency departments at the Renji Hospital (Appendix 3\&4). Hard copy surveys were compiled in Shanghai and transcribed into an electronic database in Canada and analyzed by the Canadian members of the research team.

\section{RESULTS}

Of 400 surveys distributed, 397 returned useable responses producing a $99.25 \%$ response rate. The number of patients declining to participate was not recorded, however the distribution collaborators reported less than $10 \%$ refusal to consent to the survey.

Demographic information showed an equal distribution between male and female respondents, mostly over 55 years old, with over $50 \%$ of respondents having post-secondary education but nearly $28 \%$ reported not having completed highschool level education. The majority of respondents did not speak English and over 50\% earned less than 5,000 RMB as their monthly income (the equivalent of 1,000 CAD) (Table 1). Also, less than $22 \%$ agreed that costs prevented their access to care or affected their financial wellbeing (Table 2) and $87.4 \%$ of respondents reported having Shanghai resident insurance or employer insurance (Table 1).

Furthermore, the study established that there was higher satisfaction with hospital care compared to GP care, $74.1 \%$ vs. $58.2 \%$ respectively, and that only $44.3 \%$ of respondents believed their GPs are skilful (Table 2). Although only $39.5 \%$ respondents indicated concern about waiting for hospital doctors, over $50 \%$ indicated that the time spent with physicians is not sufficient (Table 2).

On the other hand, based on a Likert scale question that removed a "neutral" response option, $68.3 \%$ of respondents agreed that they prefer a GP to a hospital doctor (Table 3). Respondents were subsequently asked to list all qualities that were factors in their preference for a GP or Hospital Doctor. The highest frequency of respondents indicated a "shorter wait time" and "closer location" as factors while a few respondents noted "longer opening hours" as a factor.

Despite this preference, less than a third of participating pa- 
Table 1. Demographic value of Sex, Education, Health Insurance, English comprehension, Income, and Age.

\begin{tabular}{|c|c|}
\hline Characteristic & Value \\
\hline Survey Multiple Choice Questions & No. (\%) of respondents \\
\hline \multicolumn{2}{|l|}{ Responding individual } \\
\hline I am completing this survey for myself (Total) & $342(86.1 \%)$ \\
\hline I am completing this survey for another person (Total) & $45(11.3 \%)$ \\
\hline N/A & $10(2.5 \%)$ \\
\hline \multicolumn{2}{|l|}{ Sex } \\
\hline Female & $208(52.4 \%)$ \\
\hline Male & $185(46.6 \%)$ \\
\hline $\mathrm{N} / \mathrm{A}$ & $4(1.0 \%)$ \\
\hline \multicolumn{2}{|l|}{ Highest Education Level } \\
\hline None & $2(0.5 \%)$ \\
\hline Elementary School & $23(5.8 \%)$ \\
\hline Middle School & $84(21.2 \%)$ \\
\hline High School & $89(22.4 \%)$ \\
\hline Diploma/Trade school & $87(21.9 \%)$ \\
\hline Undergraduate Degree & $95(23.9 \%)$ \\
\hline Postgraduate Degree & $14(3.5 \%)$ \\
\hline $\mathrm{N} / \mathrm{A}$ & $3(0.8 \%)$ \\
\hline \multicolumn{2}{|l|}{ Health Insurance Distribution } \\
\hline Shanghai resident insurance & $163(41.1 \%)$ \\
\hline Employer insurance & $184(46.3 \%)$ \\
\hline Other & $50(12.6 \%)$ \\
\hline \multicolumn{2}{|l|}{ English Comfort Level } \\
\hline Very Uncomfortable & $126(31.7 \%)$ \\
\hline Somewhat Uncomfortable & $156(39.3 \%)$ \\
\hline Neutral & $52(13.1 \%)$ \\
\hline Somewhat Comfortable & $44(11.1 \%)$ \\
\hline Very Comfortable & $14(3.5 \%)$ \\
\hline $\mathrm{N} / \mathrm{A}$ & $5(1.3 \%)$ \\
\hline \multicolumn{2}{|l|}{ Income Distribution } \\
\hline$<2500 \mathrm{RMB}$ & $71(17.9 \%)$ \\
\hline 2500-5000 RMB & $196(49.4 \%)$ \\
\hline 5000-10,000 RMB & $99(24.9 \%)$ \\
\hline $10,000-20,000$ RMB & $15(3.8 \%)$ \\
\hline $20,000 \mathrm{RMB}+$ & $7(1.8 \%)$ \\
\hline N/A & $9(2.3 \%)$ \\
\hline Survey Free Text Question & Mean (SD) [range] \\
\hline Age $(y)$ & $57.0(24.2)[19-94]$ \\
\hline \multicolumn{2}{|l|}{ Age ranges } \\
\hline $18-25$ & $12(3.0 \%)$ \\
\hline $26-35$ & $55(13.9 \%)$ \\
\hline $36-45$ & $29(7.3 \%)$ \\
\hline $46-55$ & $60(15.1 \%)$ \\
\hline $56-65$ & $101(25.4 \%)$ \\
\hline $66-75$ & $84(21.2 \%)$ \\
\hline $76-85$ & $36(9.1 \%)$ \\
\hline $86-95$ & $16(4.0 \%)$ \\
\hline N/A & $4(1.0 \%)$ \\
\hline
\end{tabular}


Table 2. Likert scale responses regarding perceptions of existing healthcare and values of family medicine.

\begin{tabular}{|c|c|c|c|c|c|c|c|c|}
\hline Survey Statements & \begin{tabular}{|r|} 
Strongly \\
Disagree \\
$(1)$
\end{tabular} & $\begin{array}{r}\text { Somewhat } \\
\text { Disagree } \\
(2)\end{array}$ & $\begin{array}{r}\text { Neutral } \\
(3)\end{array}$ & $\begin{array}{r}\text { Somewhat } \\
\text { Agree } \\
(4)\end{array}$ & $\begin{array}{r}\text { Strongly } \\
\text { Agree } \\
(5) \\
\end{array}$ & & $\begin{array}{l}\text { Percent in } \\
\text { agreement } \\
(4+5 / \text { total })\end{array}$ & Mean \\
\hline $\begin{array}{l}\text { Last time I have seen } \\
\text { my hospital doctor, I } \\
\text { have waited too long }\end{array}$ & 42 & 82 & 99 & 105 & 52 & 17 & $39.5 \%$ & 3.113 \\
\hline $\begin{array}{l}\text { I am satisfied with } \\
\text { the length of time I } \\
\text { had with hospital } \\
\text { doctors }\end{array}$ & 24 & 66 & 98 & 136 & 58 & 15 & $48.9 \%$ & 3.361 \\
\hline $\begin{array}{l}\text { I am satisfied with } \\
\text { the hospital care I } \\
\text { have received. }\end{array}$ & 4 & 9 & 75 & 208 & 86 & 15 & $74.1 \%$ & 3.950 \\
\hline $\begin{array}{l}\text { The costs of } \\
\text { healthcare have } \\
\text { previously prevented } \\
\text { my ability to get care }\end{array}$ & 85 & 139 & 88 & 53 & 20 & 12 & $18.4 \%$ & 2.439 \\
\hline $\begin{array}{l}\text { The costs of } \\
\text { healthcare have } \\
\text { previously affected } \\
\text { my financial well- } \\
\text { being }\end{array}$ & 89 & 122 & 87 & 60 & 27 & 12 & $21.9 \%$ & 2.517 \\
\hline $\begin{array}{l}\text { I see General } \\
\text { Practice Doctors as } \\
\text { skillful }\end{array}$ & 10 & 52 & 148 & 120 & 56 & 11 & $44.3 \%$ & 3.415 \\
\hline $\begin{array}{l}\text { I am satisfied with } \\
\text { the care I have } \\
\text { received from } \\
\text { General Practice } \\
\text { Doctors }\end{array}$ & 5 & 20 & 121 & 152 & 79 & 20 & $58.2 \%$ & 3.743 \\
\hline $\begin{array}{l}\text { Having access to a } \\
\text { hospital doctor } \\
\text { directly on demand is } \\
\text { a priority for me }\end{array}$ & 0 & 27 & 80 & 152 & 125 & 13 & $69.8 \%$ & 3.977 \\
\hline $\begin{array}{l}\text { Having the same } \\
\text { doctor for myself and } \\
\text { my family over time } \\
\text { is important to me }\end{array}$ & 0 & 14 & 65 & 161 & 147 & 10 & $77.6 \%$ & 4.140 \\
\hline $\begin{array}{l}\text { Having access to a } \\
\text { doctor who can take } \\
\text { care of most of my } \\
\text { concerns, while } \\
\text { coordinating care } \\
\text { and referrals with } \\
\text { hospital doctors is } \\
\text { important for me }\end{array}$ & 0 & 9 & 55 & 153 & 169 & 11 & $81.1 \%$ & 4.249 \\
\hline $\begin{array}{l}\text { I understand Family } \\
\text { Medicine doctors and } \\
\text { General Practice } \\
\text { doctors to be the } \\
\text { same }\end{array}$ & 0 & 52 & 128 & 131 & 64 & 22 & $49.1 \%$ & \\
\hline
\end{tabular}


Table 3. Likert scaled preference of GPs over a hospital doctor and the given reason(s) for their preference.

\begin{tabular}{|lr|lr|}
\hline $\begin{array}{l}\text { I prefer seeing a General } \\
\text { Practice Doctor instead of a } \\
\text { Hospital Doctor }\end{array}$ & $\begin{array}{l}\text { Why do you prefer seeing a } \\
\text { Hospital Doctor or a General } \\
\text { Practice Doctor? }\end{array}$ \\
\hline $\begin{array}{l}\text { Strongly/Some } \\
\text { what Disagree }\end{array}$ & 124 & Shorter wait time & 214 \\
\hline $\begin{array}{l}\text { Strongly/Some } \\
\text { what Agree }\end{array}$ & 267 & Closer location & 180 \\
\hline $\begin{array}{l}\text { Percent in } \\
\text { agreement }\end{array}$ & $68.3 \%$ & Lower cost & 173 \\
\hline \multirow{2}{*}{} & Higher trust & 165 \\
\cline { 2 - 3 } & Higher quality & 139 \\
\cline { 2 - 3 } & More skillful & 121 \\
\cline { 2 - 3 } & $\begin{array}{l}\text { Longer opening } \\
\text { hours }\end{array}$ \\
\cline { 2 - 3 } & & 56 \\
\end{tabular}

Table 4. Reponses regarding referrals, multiplicity of usage, and GP contracts.

\begin{tabular}{|lccc|}
\hline & Yes & No & $\%$ Yes \\
\hline $\begin{array}{l}\text { Has a specialist ever transferred you to } \\
\text { another specialist because your disease } \\
\text { does not fall under his/her profession? }\end{array}$ & 205 & 187 & $51.6 \%$ \\
\hline $\begin{array}{l}\text { Are you seeing many hospital doctors for } \\
\text { the same illness? }\end{array}$ & 237 & 154 & $59.7 \%$ \\
\hline $\begin{array}{l}\text { Have you signed a contract with a General } \\
\text { Practice Doctor? }\end{array}$ & 113 & 278 & $28.5 \%$ \\
\hline
\end{tabular}

Table 5. Compilation of ranked healthcare preferences with improperly filled rankings omitted

\begin{tabular}{|c|c|c|c|c|c|c|c|}
\hline $\begin{array}{l}\text { Please rank } \\
\text { the following } \\
\text { characteristics } \\
\text { of healthcare } \\
\text { that are most } \\
\text { important for } \\
\text { you }\end{array}$ & $\begin{array}{l}\text { Seeing } \\
\text { the } \\
\text { same } \\
\text { doctor } \\
\text { over } \\
\text { time }\end{array}$ & $\begin{array}{l}\text { Having } \\
\text { the same } \\
\text { access } \\
\text { as } \\
\text { everyone } \\
\text { else }\end{array}$ & $\begin{array}{l}\text { The best } \\
\text { care } \\
\text { possible } \\
\text { (i.e. test, } \\
\text { drugs, } \\
\text { treatment) }\end{array}$ & $\begin{array}{l}\text { Choice of } \\
\text { health } \\
\text { professional }\end{array}$ & $\begin{array}{l}\text { Lower } \\
\text { cost of } \\
\text { care }\end{array}$ & $\begin{array}{l}\text { Shorter } \\
\text { wait } \\
\text { times }\end{array}$ & $\begin{array}{l}\text { Health } \\
\text { professional } \\
\text { I can trust }\end{array}$ \\
\hline $\begin{array}{l}1 \text { (Most } \\
\text { Important) }\end{array}$ & 58 & 27 & 74 & 7 & 15 & 6 & 15 \\
\hline 2 & 30 & 38 & 44 & 19 & 22 & 24 & 25 \\
\hline 3 & 16 & 23 & 36 & 37 & 45 & 25 & 20 \\
\hline 4 & 26 & 30 & 16 & 35 & 34 & 32 & 29 \\
\hline 5 & 10 & 30 & 16 & 35 & 37 & 40 & 33 \\
\hline 6 & 26 & 22 & 9 & 30 & 26 & 50 & 38 \\
\hline $\begin{array}{l}7 \text { (Least } \\
\text { Important) }\end{array}$ & 36 & 31 & 7 & 38 & 23 & 25 & 42 \\
\hline Total & 202 & 201 & 202 & 201 & 202 & 202 & 202 \\
\hline Average & 3.604 & 3.935 & 2.559 & 4.562 & 4.119 & 4.614 & 4.594 \\
\hline
\end{tabular}


tients have signed contracts with a GP and many have had numerous specialists for their care and redirection of referrals due to inappropriate consultation (Table 4).

Most importantly, there was a high degree of agreement towards valuing principles of family medicine such as comprehensiveness and continuity of care, as reflected by the $81.1 \%$ and $77.6 \%$ agreement with statements to that effect respectively (Table 2). The majority of respondents also understood family medicine as different from General Practice (Table 2). The ranking of preferred characteristics of healthcare seems to have been misunderstood by respondents with many indicating a number of items as most important. Using only the data from those that performed the ranking exercise correctly, "having the best care possible" was the most valued characteristic followed by having "the same care provider over time" (Table 5).

\section{DISCUSSION}

A cornerstone of family medicine is to understand the social determinants and the health needs of the communities we serve. This descriptive analysis provides demographics, preferences and perceptions of the patients in Community Health Centers and tertiary care centers in Shanghai. As a result, this study also assists in understanding the social, economic and cultural challenges that the OSJSM may face in the development of family medicine training sites.

\section{DEMOGRAPHICS}

One of the highlighted demographic results is that $27.5 \%$ of those surveyed reported not having a high school level of education and $71.0 \%$ reported being somewhat or very uncomfortable with English. Although this will not be a problem for local Chinese students, North American medical students and clinicians seeking to engage with the Shanghai population will be challenged to have meaningful interactions without translators or training in the local language.

Also, despite the low income of many respondents, cost did not appear as a barrier to accessing care and most respondents reported having Shanghai resident insurance or employer insurance. However, these findings are limited by the fact that the survey was only administered to individuals already accessing healthcare, and may have excluded those for whom costs are a completely prohibitive barrier.

\section{PATIENT SATISFACTION}

One of the most significant findings was that a majority of individuals preferred seeing a General Practice physician to a Hospital Doctor (i.e. specialist). This was not predicted in our hypothesis based on prevailing accounts that Chinese patients were increasingly shifting away from centers of primary care, and towards the most highly qualified specialists [4]. The most significant contributing factors to this preference were shorter wait times, proximity in location, and lower costs.

Although the majority of respondents were satisfied with their care from GPs, there also remains a strong satisfaction with hospital care and more than half of respondents did not believe their GPs are skilful (Table 2). One explanation of the dichotomy of preference and high frequency of GP visits, versus a high satisfaction with hospital care and misperceptions of GP skilfulness may be due to distribution and access [16]. While there was a perceived decrease in quality, "shorter wait times" and "closer location", and thus timely access seems to trump quality when a patient needs to determine their preferred care provider (Table 3).

\section{PERCEPTIONS OF FAMILY MEDICINE}

Shanghai patients' perceptions of family medicine are encouraging for embarking on the introduction of this model of care in Shanghai. As noted above, the values of continuity, coordination and comprehensiveness that underpin Canadian family medicine appear to be well desired by the Chinese population studied. This is both supported by our data, as well as corroborated by other recent studies done in Guangdong province [17]. Other factors that may support a shift to more comprehensive GP care include the current limitations of patient driven selfselection of specialists (Table 4). Our results show there was a significant amount of misused resources as well as an overwhelming amount of specialists. In a well-functioning system, the family physician would provide appropriate gatekeeping, navigation of the system and reduce inappropriate referrals [16]. Specialists may at first suffer from a decrease in volume, but may consequently allow more capacity for appropriate consultation and specialty care.

\section{LIMITATIONS}

This study was limited by a number of cultural, socio-economic and methodological elements. Language barriers may have resulted in misinterpretation of survey items. The surveyors were 
physicians and trainees and this may have led to overly positive responses, as patients may have misperceived that negative responses could affect their care despite addressing this in our training protocol. Distributors were instructed to maximize privacy for respondents, but cramped examination rooms and waiting areas may have limited the candidness of responses. The use of a convenience sample that excluded those unable to access the healthcare system was balanced by distributing the survey in both hospital and community based settings.

\section{CONCLUSION}

In summary, this study rejects our hypothesis that Shanghai patients prefer specialists to GPs, but supports our hypothesis that the values underpinning family medicine would be well received. The Shanghai patients' preferences suggest that family medicine may be welcomed if it is able to provide continuity, coordination and comprehensiveness of care and can ensure patients are receiving high quality care. This study also highlights the social, economic, and cultural challenges that the OSJSM may face in developing new family medicine training sites in Shanghai. Overall, these findings are encouraging to the development of primary care in Shanghai. However, further research will be required to validate and clarify the analyses made in this study. Also, if the OSJSM is to succeed at training future family physicians in Shanghai, parallel research will be needed to understand the primary factors that affect Chinese medical students' career preferences, since currently only $4.6 \%$ of SJTUSM students choose general practice as their preferred career paths [18].

\section{ACKNOWLEDGMENTS}

Special thanks to collaborating physicians and residents at the Renji Hospital, Cao Jiao Du and Tangqiao Community Health Centers. We would also like to thank Jingjing Chen at the Office of Internationalization for her administrative and translational support as well as Aili Wang and Sunny Xia for their help in data entry. Finally, we would like to thank Diana Fox for her help in this ethics approval process, and Zahra Montazeri for her help in statistical programming and analysis.

\section{CONFLICTS OF INTEREST}

None.

\section{REFERENCES}

1. Chan CS, Cheng Y, Cong Y, et al. Patient-physician trust in China: a workshop summary. Lancet. 2016;388 Suppl 1:S72.

2. World Bank Group; World Health Organization; Ministry of Finance PRC, et al. Deepening Health Reform in China: Building High-Quality and Value-
Based Service Delivery. Washington, DC: World Bank, 2016.

3. Starfield B, Shi L, Macinko J. Contribution of Primary Care to Health Systems and Health. The Milbank quarterly. 2005;83(3):457-502.

4. Wang H, Gusmano MK, Cao Q. An evaluation of the policy on community health organizations in China: Will the priority of new healthcare reform in China be a success? Health Policy. 2011;99(1):37-43.

5. Chen $Z$. Launch of the health-care reform plan in China. Lancet. 2009;373(9672):1322-4.

6. Wu D, Lam TP. Underuse of Primary Care in China: The Scale, Causes, and Solutions. J Am Board Fam Med. 2016;29(2):240-7.

7. Li H, Qian $D$, Griffiths $S$, et al. What are the similarities and differences in structure and function among the three main models of community health centers in China: a systematic review. BMC Health Serv Res. 2015;15:504.

8. Zhu J, Li W, Chen L. Doctors in China: improving quality through modernisation of residency education. The Lancet. 2016;388(10054):1922-9.

9. Dai $H$, Fang L, Malouin RA, et al. Family medicine training in China. Fam Med. 2013;45:341-44.

10. Canadian Medical Association. Number of Physicians by Province/Territory and Specialty, Canada, 2016. In: Canadian Medical Association, editor. Ottawa 2016.

11. Blumenthal D, Hsiao W. Lessons from the East - China's Rapidly Evolving Health Care System. New England Journal of Medicine. 2015;372(14):12815.

12. OSJSM. History of the Joint School Shanghai [Internet]. Shanghai, China: Renji Hospital, Shanghai Jiao Tong School of Medicine; 2016 [updated September 30 2017; cited 2017 September 30]. Available from: https://med. uottawa.ca/joint-school/about-us/history-joint-school.

13. CACMS. Standards for accreditation of medical education programs leading to the MD degree. Ottawa, Ontario: AFMC, 2015.

14. Foster M. Exporting our medical model [Internet]. Ottawa, (ON): University of Ottawa, Department of Medicine; 2015 October 17 [cited 2017 December 10]. Available from: https://www.uottawa.ca/tabaret/en/content/ exporting-our-medical-model.

15. Health Quality Ontario. Primary Care Patient Experience Survey: Support Guide. Health Quality Ontario. 2015.

16. Wu D, Lam TP. Underuse of Primary Care in China: The Scale, Causes, and Solutions. The Journal of the American Board of Family Medicine. 2016;29(2):240-7.

17. Kuang $L$, Liang $Y$, Mei J, et al. Family practice and the quality of primary care: a study of Chinese patients in Guangdong Province. Fam Pract. 2015;32(5):557-63.

18. Yang J, Bao Y. Key problems in sustainable development of training of general practitioners in Shanghai. 2012;32:1364-72. 
Appendix 1.

8/7/2015

\section{Shanghai Health Care Patient Survey}

Please read and fill out consent form for information and signature before continuing.

${ }^{*}$ Required

1. Are you completing this survey for yourself or for another person? * Mark only one oval.

I am completing this survey for myself Skip to question 3.

I am completing this survey for another person

2. If you are completing this survey for someone else, who are your completing it for? * Mark only one oval.

I am completing this for a family member or friend

I am completing this for the patient or client

Other:

\section{Demographics}

3. What is your birth year? * YYYY

4. Are you female or male? * Mark only one oval.
Female
Male

5. Highest level of education you have completed * Mark only one oval.
Elementary School
Middle School
High School
Diploma/Trade school
Undergraduate Degree
Postgraduate Degree 
6. What type of health insurance do you have? (check all that apply) * Check all that apply.

Shanghai resident insurance

Employer insurance

None

Other:

7. Level of comfort in English conversation? Please circle your answer: * Mark only one oval.
Very Comfortable
Somewhat Comfortable
Neutral
Somewhat Uncomfortable
Very Uncomfortable

8. How much do you earn per month? *

Mark only one oval.
$<2500 \mathrm{RMB}$
2500-5000 RMB
5000-10,000 RMB
$10,000-20,000$ RMB
$20,000 \mathrm{RMB}+$

\section{Current Use of Health Care System}

9. Check all the services you have used in the past two years and please indicate the number of visits for each: *

Please fill in others if applicable

Mark only one oval per row.

Community Clinic/General
Practitioners
Emergency Room
Hospital Doctor
(secondary/tertiary hospital)
Traditional Chinese Medicine
Others:


10. Has a specialist ever transferred you to another specialist because your disease does not fall under his/her profession? *

Mark only one oval.

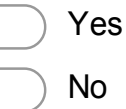

11. Are you seeing many hospital doctors for the same illness? *

Mark only one oval.

Yes

No

12. Please indicate whether you agree with the following statements * Mark only one oval per row.

Strongly Somewhat
Agree
my hospital doctor, I
have waited too long
I am satisfied with the
length of time I had with
hospital doctors
I am satisfied with the
hospital care I have
received.

\section{Health Care and Associated Costs}

13. Did you spend money out-of-pocket on related healthcare costs in the last year? If yes, please specify in RMB:

Mark only one oval per row.

Yes No If yes, please give an estimate in RMB

Secondary/Tertiary care fees:
Primary care fees:
Drug cost:
Medical examinations cost
Travel costs:
Insurance cost:
Uninsured medical costs:


14. Please indicate whether you agree with the following statements * Mark only one oval per row.

Strongly
The comewhat
have previously
prevented my ability to
get care
The costs of healthcare
have previously affected
my financial well-being

\section{General Practice in Shanghai}

15. Have you signed a contract with a General Practice Doctor?

Mark only one oval.

Yes
No

16. I prefer seeing a General Practice Doctor instead of a Hospital Doctor * Mark only one oval.
Strongly Agree
Somewhat Agree
Somewhat Disagree
Strongly Disagree

17. Why do you prefer seeing a Hospital Doctor or a General Practice Doctor? *

Please answer based on your response to question 16

Check all that apply.
Higher quality
Lower cost
Shorter wait time
Higher trust
Longer opening hours
Closer location
More skillful
Other: 
18. Please indicate whether you agree with the following statements * Mark only one oval per row.

I see General Practice
Doctors as skillful
I am satisfied with the
care I have received
from General Practice
Doctors

\section{Family Medicine Perceptions in Shanghai}

Definition of Family Medicine: The Medical Specialty devoted to training expert clinicians delivering comprehensive health care to people of all ages through the frame of a sustained partnership with patients in the context of the family and the community.

19. Please rank the following characteristics of healthcare that are most important for you

Please select each rank only once; 1 = most important, 7 = least important Mark only one oval per row.

Seeing the same doctor over
time
Having the same access as
everyone else
The best care possible (i.e.
test, drugs, treatment)
Choice of health professional
Lower cost of care
Shorter wait times
Health professional I can
trust


20. Please indicate whether you agree with the following statements * Mark only one oval per row.

Strongly Somewhat
having access to a
on demand is a priority
for me
Having the same doctor
for myself and my family
over time is important to
me
Having access to a
doctor who can take
care of most of my
concerns, while
coordinating care and
referrals with hospital
doctors is important for
me
I understand Family
Medicine doctors and
General Practice doctors
to be the same

Powered by

E Google Forms 


\section{Appendix 2.}

8/19/2015

\section{上海医疗保健患者调查}

在填写以下问卷前, 请阅读并签署同意书

*必填

1. 请问您是本人填写此份问卷, 还是替别人作答? * 请仅选择一个答案。

$\bigcirc$ 我是本人 跳转到问题 3 。

$\bigcirc$ 我是替别人作答

2. 如果您是带人作答, 请问您是具体为谁填写的? * 请仅选择一个答案。

$\bigcirc$ 我是为家庭成员或者朋友填写的

$\Longrightarrow$ 我是为患者或者来访者填写的

○其他:

\section{人口统计学}

3. 您的出生年份是? * YYYY

4. 您的性别是? *

请仅选择一个答案。

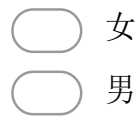

5. 您最高受教育水平是? * 请仅选择一个答案。
小学
初中
$\bigcirc$ 高中
大专/中专
本科
$\bigcirc$ 研究生及以上学历 
6. 请问您是哪种医疗保险? *

请填充

请选择所有适用项。

$\square$ 上海市民保险

$\square$ 职工医疗保险

$\square$ 无

其他:

7. 请问您对英文对话的接受程度? *

请仅选择一个答案。

$\bigcirc$ 非常能够接受

基本可以接受

$\bigcirc$ 中立

$\bigcirc$ 不太能够接受

$\bigcirc$ 非常不接受

8. 请问你每月的收入是多少? *

单选

请仅选择一个答案。

2500-5000 RMB

5000-10,000 RMB

10,000-20,000 RMB

$20,000 \mathrm{RMB}+$

现阶段医疗保健系统的使用

9. 在最近的两年中, 您是否使用过以下服务? 如果有, 请标出使用次数。* 请其他填充（如适用）

请在每行中仅选择一个答案。

社区诊所/全科医生
急诊
医院医生 (二级或者三级医院)
中医
其他 ( )


10. 您是否有过以下经历: 专科医生认为不是本科室疾病而建议去您去其他专科就诊? * 请仅选择一个答案。
是
$\bigcirc$ 否

11. 请问您是否曾经因为同一疾病去过不同的医院? * 请仅选择一个答案。

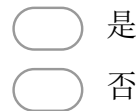

12. 请问您是否同意以下说法 * 请在每行中仅选择一个答案。

非常同意 基本同意 中立 基本不同意 完全不同意

上次我来医院就诊时，等医生的时 间非常长

我对去医院就诊时的等待时间表示 满意

我对我接收到的医院提供的治疗表 示满意

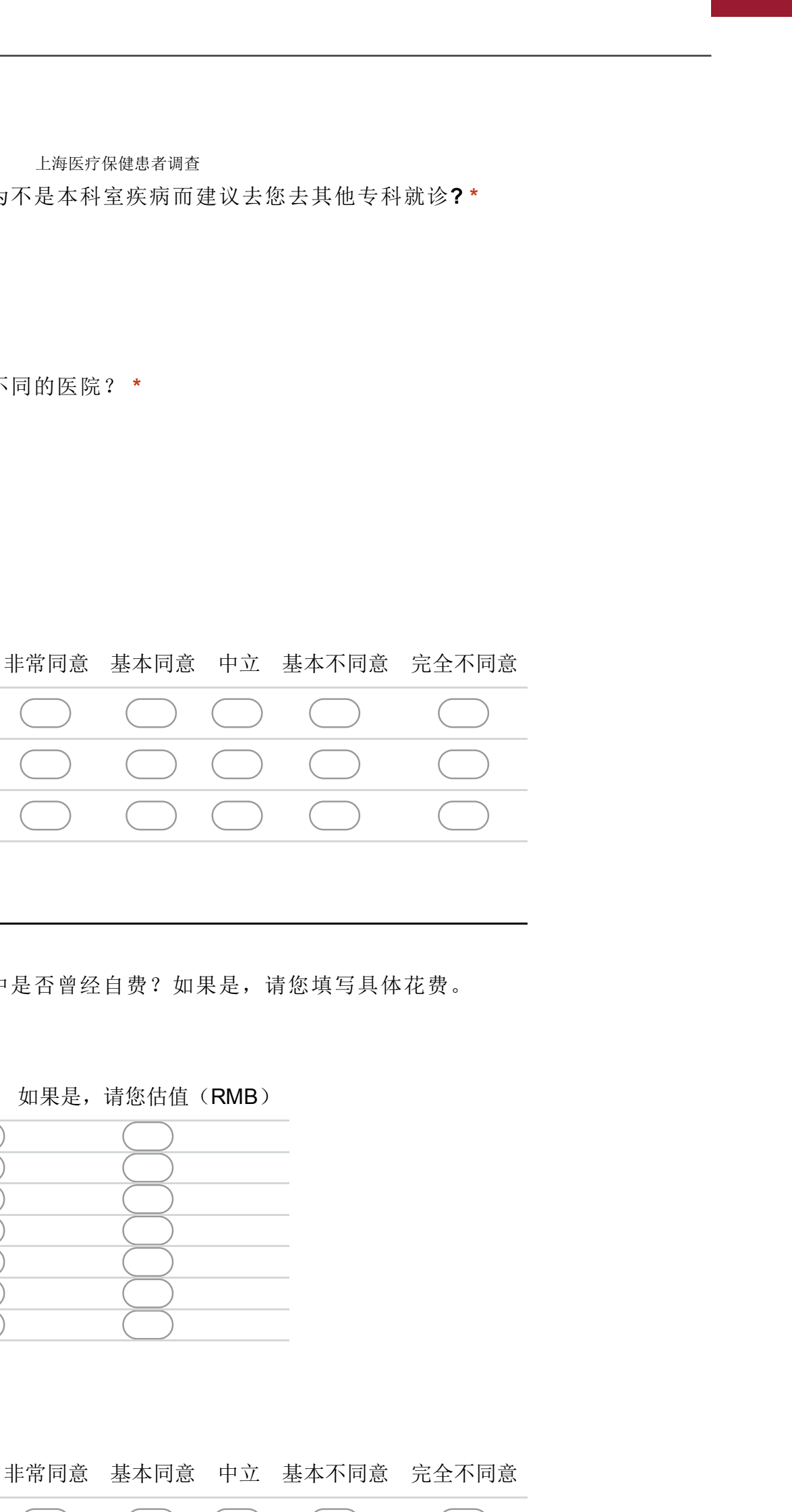

\section{医疗保健和相关花费}

13. 最近一年, 您在一下健康医疗项目中是否曾经自费? 如果是, 请您填写具体花费。 请其他填充 (如适用)

请在每行中仅选择一个答案。

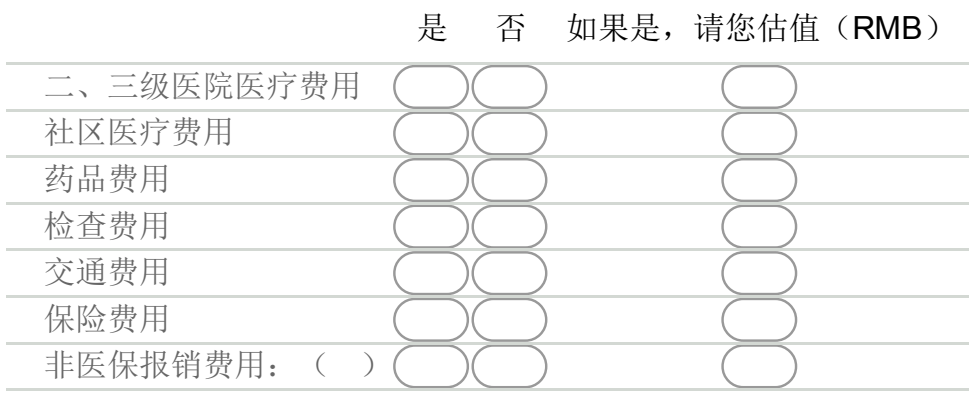

14. 请您指出您是否同意一下说法? * 请在每行中仅选择一个答案。

非常同意 基本同意 中立 基本不同意 完全不同意

医疗保健的费用曾经一度让我无法 就诊或获治

医疗保健的费用曾经影响了我的财 政情况

\section{上海全科医生概况}


15. 请问您是否与一位全科医生签约? 请仅选择一个答案。
$\bigcirc$ 是
$\bigcirc$ 否

16. 比起去医院看医生, 我更倾向于看全科医生 * 请仅选择一个答案。

非常同意

基本同意

基本不同意

完全不同意

17. 请问你更倾向于看医院医生或者全科医生的原因是? *

基于16题继续回答

请选择所有适用项。

口质量更高

口花费更少

—等待时间更少

—更高信任度

口开诊时间更长

$\square$ 诊所离住址更近

口医术更娴熟

其他:

18. 请指出您是否同意以下说法? *

请在每行中仅选择一个答案。

非常同意 基本同意 中立 基本不同意 完全不同意

我认为全科医生医术更㛠熟
我很满意我在全科医生处获得的医
疗保健治疗

\section{对上海家庭医生概况的感知}

家庭医生定义: 是在家庭和社区的背景下, 通过与患者保持持续性的关系, 致力于培养为所有年龄 的人提供全面健康保健治疗的医疗专业。 
19. 请标出一下医疗保健项目在您心目中的重要等级 * 每行仅限单选; $1=$ 最重要, $7=$ 最不重要 请在每行中仅选择一个答案。

固定看同一位医生
医疗就诊机会人平等
所能够得到的最好的治疗 (比如:
检查、约品和治疗)
自由地选择医疗人员
治疗花费更少
等待时间更短
对医疗行业的信任度

20. 请指出您是否同意以下说法？ *

请在每行中仅选择一个答案。

非常同意 基本同意 中立 基本不同意 非常不同意

直接看专科医生对我来说很重要 有固定的一位医生对我和我的家庭 很重要。 有一位医生可以照顾我大部分的健 康医疗问题, 同时适当转诊医院专 科医生, 对我来说很重要 我了解到家庭医生和全科医生是一 样的

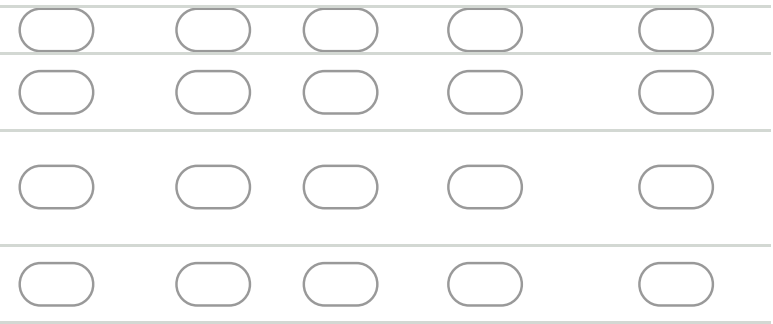


Appendix 3.

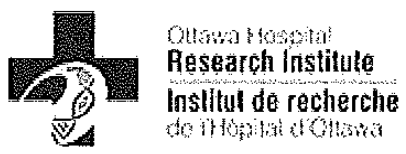

Iiii

uOttawa $\infty$

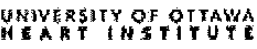
HHFTITUT OE EAgDIOLOGIE

Ottawa Health Science Network Research Ethics Board/Conseil d'éthique de la recherche du Réseau de science de la santé d'Ottawa

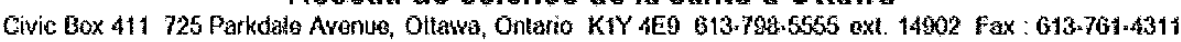

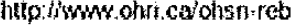

August 11,2015

Dr. Kyle Ng

600 Peter Morand Crescent (101H)

Ottawa, ON K1G $5 Z 3$ Canada

Dear Dr. $\mathrm{Ng}$ :

\section{Re: Protocol \# 20150491- Study of Patient Healthcare in Shanghai for the Establishment a Family $01 \mathrm{H}$ Medicine Demonstration Clinic}

Protocol approval valid until - $\quad$ August 10, 2016

I am pleased to inform you that this protocol underwent delegated review by the Ottawa Health Science Network Research Ethics Board (OHSN-REB) and is approved. No changes, amendments or addenda may be made to the protocol or the consent form without the OHSN-REB's review and approval.

APPROVAL IS CONDITIONAL UPON RECEIPT OF THE RENJI HOSPITAL RESEARCH ETHICS BOARD APPROVAL.

Approval is for the following:

- Protocol dated June 23, 2015

- English Shanghai Health Care Patient Survey, uploaded August 11, 2015

- English Participant Informed Consent Form (version 1) dated July 27, 2015

Your request for a French exemption is approved. Please provide the Mandarin Chinese versions of the consent form and survey once available.

The REB no longer requires a 'valid until' date at the bottom of all approved informed consent forms. The consent forms currently approved for use by the REB are listed above.

If the study is to continue beyond the expiry date noted above, a Renewal Form should be submitted to the REB approximately six weeks prior to the current expiry date. If the study has been completed by this date, a Termination Report should be submitted.

The Ottawa Health Science Network Research Ethics Board (OHSN-REB) was created by the merger of both the Ottawa Hospital Research Ethics Board (OHREB) and the Human Research Ethics Board (HREB) for meetings held at the University of Ottawa Heart Institute. 
OHSN-REB complies with the membership requirements and operates in compliance with the Tri-Council Policy Statement: Ethical Conduct for Research Involving Humans; the International Conference on Harmonization -

Good Clinical Practice: Consolidated Guideline and the provisions of the Personal Health Information Protection Act 2004.

Yours sincerely,

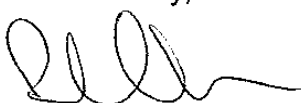

Raphael Saginur, M.D.

Chairperson

Ottawa Health Science Network Research Ethics Board

$\mathrm{RS} / \mathrm{kd}$ 


\section{Appendix 4.}

\section{上海交通大学医学院附属仁济医院伦理委员会 科研伦理审批件}

\begin{tabular}{|c|c|}
\hline 研究项目名称 & 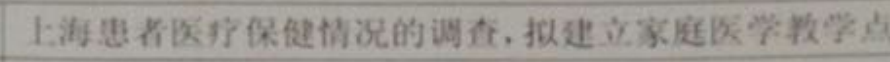 \\
\hline 项目米源 & 研究者白发 \\
\hline 项目织照 & 1 \\
\hline 项目负责人 & Kyle Ng \\
\hline 项目承担科室 & 湹太华矤学院家庭医学系、亿济医院老年病科 \\
\hline 主要研究者 & 古超等 \\
\hline 伦理审查方式 & $\square$ 会议伸查 口快速审金 \\
\hline 年查意见 & 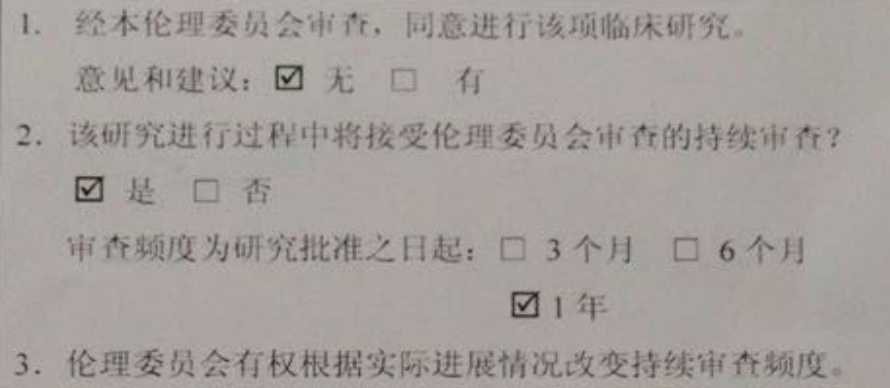 \\
\hline
\end{tabular}

注意:

1. 已批准项目必须遂循本伦理审全委员会批准的方案执行, 必须符合 SFDA/GCP 和 《赫尔辛基宣言》的原则。

2. 暂停/提前终此临床研究, 请及时通知伦理委员会。

3. 发生严重不良事件及影响研究风险受臬比的非顶期事作，必须及时报告本伦理委 员会。

4. 对已批准的临床研究方案、知情同意挤等材料的任何修改及主要研究者更换等, 必须及时通知本伦理委员会重新审并, 获得批准后执行。

5. 发现追反方案情况必须及时报告。

6. 根据伦理审在委员会对待持续审杏频度的意见, 无论试验开始与否, 请在持续审 在日期前 1 个月提出持续审查的申请。

7. 完成临床研究, 必须交结题报告供伦理委员会审枯。

上海交通大学医学院附属仁济医院伦理委员会

日期: 2015 年 8 月 18 日

*本批作:一式一份, 由课题组保存, 遗失不补。 